\title{
Anticancer drugs for the modulation of endoplasmic reticulum stress and oxidative stress
}

\author{
Ammad Ahmad Farooqi ${ }^{1} \cdot$ Kun-Tzu $\mathrm{Li}^{2} \cdot$ Sundas Fayyaz $^{3}$ - Yung-Ting Chang ${ }^{4}$. \\ Muhammad Ismail $^{1}$ - Chih-Chuang Liaw ${ }^{4,5}$ - Shyng-Shiou F. Yuan ${ }^{6,7}$. \\ Jen-Yang Tang ${ }^{8,9,10}$ • Hsueh-Wei Chang ${ }^{2,7,11,12}$
}

Received: 31 May 2015 / Accepted: 10 July 2015 / Published online: 19 July 2015

(C) The Author(s) 2015. This article is published with open access at Springerlink.com

\begin{abstract}
Prior research has demonstrated how the endoplasmic reticulum (ER) functions as a multifunctional organelle and as a well-orchestrated protein-folding unit. It consists of sensors which detect stress-induced unfolded/misfolded proteins and it is the place where protein folding is catalyzed with chaperones. During this folding process, an immaculate disulfide bond formation requires an oxidized environment provided by the ER. Protein folding and the generation of reactive oxygen species (ROS) as a protein oxidative byproduct in ER are crosslinked. An ER stress-induced response also mediates the expression of the apoptosis-associated gene C/EBP-homologous protein
\end{abstract}

Jen-Yang Tang

reyata@kmu.edu.tw

Hsueh-Wei Chang

changhw@kmu.edu.tw

Ammad Ahmad Farooqi

ammadfarooqi@rlmclahore.com

Kun-Tzu Li

sherry30126@yahoo.com.tw

Sundas Fayyaz

Sundas.khan23@yahoo.com

Yung-Ting Chang

poppiiyy@gmail.com

Muhammad Ismail

m.ismai102@gmail.com

Chih-Chuang Liaw

cchuangliaw@gmail.com

Shyng-Shiou F. Yuan

yuanssf@ms33.hinet.net

1 Institute of Biomedical and Genetic Engineering (IBGE), KRL Hospital, Islamabad, Pakistan
(CHOP) and death receptor 5 (DR5). ER stress induces the upregulation of tumor necrosis factor-related apoptosis inducing ligand (TRAIL) receptor and opening new horizons for therapeutic research. These findings can be used to maximize TRAIL-induced apoptosis in xenografted mice. This review summarizes the current understanding of the interplay between ER stress and ROS. We also discuss how damage-associated molecular patterns (DAMPs) function as modulators of immunogenic cell death and how natural products and drugs have shown potential in regulating ER stress and ROS in different cancer cell lines. Drugs as inducers and inhibitors of ROS

2 Department of Biomedical Science and Environmental Biology, Kaohsiung Medical University, Kaohsiung, Taiwan

3 Laboratory for Translational Oncology and Personalized Medicine, RLMC, Lahore, Pakistan

4 Doctor Degree Program in Marine Biotechnology, National Sun Yat-sen University/Academia Sinica, Kaohsiung, Taiwan

5 Department of Marine Biotechnology and Resources, National Sun Yat-sen University, Kaohsiung, Taiwan

6 Translational Research Center, Kaohsiung Medical University Hospital, Kaohsiung Medical University, Kaohsiung, Taiwan

7 Cancer Center, Kaohsiung Medical University Hospital; Kaohsiung Medical University, Kaohsiung, Taiwan

8 Department of Radiation Oncology, Faculty of Medicine, College of Medicine, Kaohsiung Medical University, Kaohsiung, Taiwan

9 Department of Radiation Oncology, Kaohsiung Medical University Hospital, Kaohsiung, Taiwan

10 Department of Radiation Oncology, Kaohsiung Municipal Ta-Tung Hospital, Kaohsiung, Taiwan

11 Institute of Medical Science and Technology, National Sun Yat-sen University, Kaohsiung, Taiwan

12 Research Center of Environmental Medicine, Kaohsiung Medical University, Kaohsiung, Taiwan 
modulation may respectively exert inducible and inhibitory effects on ER stress and unfolded protein response (UPR). Reconceptualization of the molecular crosstalk among ROS modulating effectors, ER stress, and DAMPs will lead to advances in anticancer therapy.

Keywords Anticancer $\cdot$ ER stress $\cdot$ ROS $\cdot$ Natural products

\section{Introduction}

\section{ER stress}

Endoplasmic reticulum (ER) provides suitable folding to generate functional proteins. When the cellular environment changes or cells are affected by DNA damage and oxidative stress, misfolding proteins may accumulate in the ER leading to increased ER stress. In response to ER stress, cells activate a series of signaling proteins called unfolded protein response (UPR) which favors suitable ER protein folding [1]. Both ER stress and UPR activation are commonly reported in many different cancers. Information obtained from high throughput technologies has substantially improved our understanding of the UPR. This particularly holds for stress sensors that balance ER homeostasis in the protection of cell viability for mild ER stress [2] or leads to intrinsic mitochondrial apoptosis [3] for severe ER stress [4].

Rapidly emerging evidence highlight the key roles of versatile regulators, particularly inositol-requiring protein $1 \alpha$ $($ IRE1 $\alpha$ ), protein kinase RNA-like endoplasmic reticulum kinase (PERK), and activating transcription factor 6 (ATF6) in transducing information from the ER to the cytosol and nucleus to mediate biological activities $[1,2,5,6]$. It is known that immunoglobulin-heavy-chain-binding protein (GRP78/ BIP)-bound stress sensors remain inactive and unfolded protein accumulations in the ER induce the activation of ATF6, IRE1 $\alpha$, and PERK [7]. Unbinding GRP78 from ATF6 exposes Golgi-localization sequence (GLS) within ATF6 [8] to guide the protein to Golgi by interacting with the coat protein II (COPII) complex [9], and within Golgi, it undergoes proteolytic processing by site-1 protease (S1P) and site-1 protease (S2P) [10]. The proteolytically processed ATF6 fragment (ATF6f) acts as a transcription factor and moves into the nucleus to transcriptionally upregulate target genes, including GRP78, C/EBP-homologous protein (CHOP), and X-box binding protein 1 (XBP1) [1, 11]. Unbinding of GRP78 from IRE1 induced homodimer formation and the activation of IRE1 through autophosphorylation [12]. Phospho-IRE1 excises a 26-bp fragment from unspliced XBP1 messenger RNA (mRNA) to form spliced XBP1s mRNA after religation [13]. Nuclear accumulation of XBP1 protein follows binding to UPR elements (UPREs) to trigger target genes. PERK-induced phosphorylation of phospho-eukaryotic initiation factor-alpha (eIF2 $\alpha$ ) results in translational inhibition [14]. However, ATF4 mRNA escapes eIF2 $\alpha$-mediated translational suppression [15]. ATF4 transcriptionally upregulated CHOP and protein phosphatase 1 regulatory subunit 15A (PPP1R15A; GADD34) [16]. eIF2 $\alpha$ dephosphorylation was triggered by GADD34-bound protein phosphatase 1C (PP1C) [17]. Next, we discuss another widely studied mechanism of cellular oxidative stress in ER.

\section{Oxidative stress}

The biology of free radical generation has attracted considerable scientific interest, and we now categorically know that two mechanisms mediate the generation of reactive oxygen species (ROS). Oxidative folding machinery induced by UPR in the ER and mitochondria is associated with free radical generation. Both ROS and reactive nitrogen species (RNS) are generated in response to different cellular stresses and as byproducts of normal cellular metabolism [18]. ROS and RNS have opposite roles at varying concentrations. For example, high concentrations of these species induced cellular damage but was reported to be advantageous at low/moderate concentrations while working synchronously with cellular antioxidant defense mechanisms which detect, respond to, and transmit these signals to maintain cellular redox homeostasis [19]. In addition, NADPH oxidases (NOX) are responsible for ROS generation. The modulation of NADPH oxidases by natural products may change the ROS level [20].

Oxidative stress is a condition in which ROS is overproduced and cannot be balanced by the available antioxidant machinery. Mitochondria are the major production sites of the superoxide anion ozone (triplet stage molecular oxygen) that later forms secondary species, namely hydroxyl radical, hydrogen peroxide, hydroperoxyl radical, and hypochlorous acid [21]. Proper folding of proteins is a critical and multistep process and requires an oxidizing-folding environment. This particularly sensitive procedure is ROS dependent and occurs in the ER where disulfide bond formation takes place during the folding process. For example, the ER membraneassociated oxidoreductin (ERO-1) uses a flavin adenine dinucleotide (FAD)-dependent procedure to transfer electrons from the 58-kDa protein disulfide isomerase of the ER (PDI) [22] to molecular oxygen to oxidize PDI. If the machinery recognizes faulty disulfide bonds, glutathione (GSH) reduces disulfide bonds [23]. This way, the reduced glutathione/ oxidized glutathione (GSSH) ratio is decreased.

Increased protein-folding load in the ER may result in the accumulation of ROS [1], and cells have evolved various mechanisms to limit overproduction of free radicals. Accordingly, PERK mediates phosphorylation of the nuclear factor and erythroid 2-like 2 (NFE2L2; NRF2) [24] to facilitate its accumulation in the nucleus to upregulate the expression of a set of oxidant-detoxifying and antioxidant enzymes. 
This holds, for example, for NAD(P)H-quinone oxidoreductase, heme-oxygenase 1 (HO-1), and glutathione S-transferase (GST) [25]. Nrf2-mediated HO-1 upregulation was found in sulforaphane-treated bladder cancer T24 cells [26]. More importantly, it has been shown that the ER stress-inducing chemical tunicamycin weakly induced ROS accumulation in PERK competent cells [27]. However, ROS accumulation was markedly enhanced in PERK-deficient cells. This ROS-mediated cell death was partly rescued by antioxidant $N$-acetyl-L-cysteine (NAC) [27], suggesting that oxidative stress contributes to PERK-mediated ER stress signaling. Next, we will discuss how ROS causes ER stress.

\section{Interplay of ROS and ER stress}

It is noteworthy that PERK deficiency may suppress ROSinduced ER stress leading to apoptosis in cancer cells [27]. Stable transfection of shRNA-PERK in breast cancer MDAMB468 cells impaired ROS-mediated ER stress induction. Surprisingly, PERK was noted to be a component of the protein network connecting ER to mitochondria [28, 29]. It has been shown experimentally that PERK $+/+$ murine embryonic fibroblast (MEF) cells had mitochondria interwoven with the ER network. However, in PERK-/- MEF cells, co-localization of mitochondria with ER was considerably lower [30].

Long-term ER stress may trigger two major pro-apoptotic pathways [31-34]. One involves c-Jun N-terminal kinase (JNK) and p38 mitogen-activated protein kinase (MAPK), while the other involves CHOP. Accumulation of IREmediated activation of JNK and p38 MAPK-mediated activation may lead to apoptosis $[35,36]$. Other pro-apoptotic factors may be transcriptionally activated by CHOP $[37,38]$.

For the JNK pathway, an antimicrobial peptide pardaxin, synthesized by the red sea flatfish Pardachirus marmoratus [39], was used as an example. Pardaxin was reported to contribute to antiproliferation and inducible apoptosis in several cancer cells [40-42]. Both PERK activity and eIF2 $\alpha$ were noted in pardaxin-treated HeLa cells [43]. The nuclear translocation of ATF6 also indicated that pardaxin induced ER stress in HeLa cells. Pardaxin also induced ROS production to activate AP-1/c-Jun and NAC can revert it. C-Jun was also demonstrated to be essential for apoptosis as caspase-3/-7 activity was inhibited by c-Jun small interfering RNA (siRNA) silenced cells. Therefore, it was concluded that both ER stress and ROS-induced c-Jun were activated and reciprocally regulated in pardaxin-treated cancer cells [43]. Similar ROSinducible activation of $\mathrm{JNK}$ was noted in berberine-treated breast cancer MDA-MB-231 and MCF-7 cells [44]. It subsequently triggered mitochondrial membrane depolarization and led to apoptosis, although the role of ER stress in berberine treatment was not addressed.

Interestingly, SMIP004 (N-(4-butyl-2-methyl-phenyl) acetamide) was reported to induce the activation of $\operatorname{eIF} 2 \alpha$ and
IRE1 for apoptosis in prostate cancer cells and it was rescued by siRNA application to knockdown both of them [45]. SMIP004 was also demonstrated to trigger both JNK and p38 activity. Moreover, a decreased ratio of the reduced form of GSH to oxidized GSH and ROS accumulation indicated that SMIP004-induced apoptosis occurred through both ER stress mechanisms. Sarsasapogenin, isolated from the plant Anemarrhena asphodeloides Bunge, effectively induced apoptosis via the upregulation of CHOP in HeLa cells [46]. Moreover, sarsasapogenin-induced ROS generation was markedly inhibited upon NAC treatment, suggesting that drug-induced ROS mediates ER stress.

Synthetic polyphenol conjugate, (E)-3-(3,5dimethoxyphenyl)-1-(2-methoxyphenyl)prop-2-en-1-one (DPP-23), also induces ROS-mediated apoptosis in several cancer cells, and tumor growth was reduced in mice xenografted with human colon cancer HCT116 cells [47]. Knockdown with siRNA IRE1 $\alpha$ was reported to inhibit caspase-4 cleavage in DPP-23-treated human pancreatic cancer MIA PaCa-2 cells. Accordingly, UPR was involved in DPP-23-induced apoptosis. DPP-23 dose-responsively induced the ROS generation in MIA PaCa- 2 cells but not for primary normal pancreatic cells. The oxidative stress role of DPP-23-induced apoptosis was further validated by the finding that NAC recovered DPP-23-induced GSH depletion in PaCa-2 cells. Therefore, DPP-23 displayed selective ROS generation in pancreatic cancer MIA $\mathrm{PaCa}-2$ cells but not for normal pancreatic cells. It also demonstrated that oxidative stress is an upstream event of ER stressmediated apoptosis [47].

Carnosic acid, isolated from extracts of rosemary, was noted to effectively enhance CHOP and ATF4 in renal carcinoma Caki cells [48]. ROS was also enhanced in carnosic acidtreated cancer cells, and NAC considerably reduced carnosic acid-induced CHOP and ATF4 expression. Bortezomib and dipyridamole worked with effective synergy to enhance ER stress in treated cancer cells [49]. Importantly, relieving ER stress by protein translation inhibitor cycloheximide impaired drug-induced apoptosis. In addition, bortezomib and dipyridamole treatment-depleted GSH and ROS levels were drastically enhanced in leukemia and lymphoma cells [49].

\section{Damage-associated molecular patterns}

Stressed, injured, or dying cells release or flag certain molecules on their outer plasma membrane that are functionally not immunogenic within cells [50]. However, these molecules can initiate an immunological response if released extracellularly or displayed at the cell surface. These signals are termed damage-associated molecular patterns (DAMPs) [51]. Some DAMPs are passively released, namely high mobility group proteins B1 (HMGB1). In contrast, some are actively secreted 
like adenosine triphosphate (ATP) and others (calreticulin (CRT) and heat shock protein (HSP)-90), which appear on the cell surface or accumulate on the outer leaflet of the plasma membrane.

PERK induces phosphorylation of the eIF $2 \alpha$-facilitated shipping of CRT from ER to the Golgi apparatus [52]. Mechanistically, it has been shown that targeted inhibition of PERK and/or phosphatidylinositol-4,5-bisphosphate 3-kinase, catalytic subunit alpha (PIK3CA; PI3K)/v-akt murine thymoma viral oncogene homolog (AKT) dramatically reduced the CRT translocation [53]. For example, DNAdependent protein kinase, a catalytic subunit (DNA-PKcs)mediated phosphorylation of AKT, appeared to be necessary for the cell surface appearance or CRT. Wogonin (5,7-dihydroxy-8-methoxyflavone) was noted to effectively functionalize these pathways in gastric carcinoma MKN-45 cells [53]. Immunogenic cell death (ICD) is stress dependent and requires ROS-based ER stress [54]. Several sources indicated that ER stress and ROS synergistically activated danger signaling pathways that contributed to mobilization of DAMPs to the extracellular space [55]. Surprisingly, combining tunicamycin or thapsigargin with a chemotherapeutic drug may induce apoptosis with an immunogenic effect in nature as well [56]. It is concluded that ROS production and ER stress are critical for ICD, and simultaneous induction is vital to induce immunogenicity. ROS production and ER stress considerably enhanced different types of DAMP emission.

It has recently been convincingly demonstrated that ICDassociated immunogenicity is significantly increased when type II ICD inducers are used. Hypericin-based photodynamic therapy (PDT) is primarily a type II ICD inducer and operates through ROS-based ER stress. Mechanistically, it has been shown that hypericin is a photosensitizer that promotes substantially enhanced ROS generation upon excitation by specific wavelength thus resulting in a targeted ROS-based ER stress. Rapidly emerging evidence has shown that PDT induces ICD in cancer cells [54, 57]. Vaccination of C57BL/6 mice with PDT-treated Lewis lung carcinoma (LLC) alone or dendritic cells pulsed with PDT-treated LLCs revealed considerably improved immunological responses against Lewis lung carcinoma [58].

\section{TRAIL-induced signaling and ER stress}

Tumor necrosis factor-related apoptosis-inducing ligand (TRAIL)-mediated signaling has emerged as one of the most extensively studied pathways reported to selectively induce apoptosis in cancer cells [59]. TRAIL signals intracellularly through death receptors which belong to the tumor necrosis factor receptor superfamily. Death receptors (DR4 and/or DR5) possess a cytoplasmic death domain (DD). Deathinducing signaling complex containing FADD and pro- caspase- 8 appear at the death receptor. However, rapidly accumulating experimental evidence has also revealed that the expression and cell surface appearance of DRs is notably reduced in TRAIL-resistant cancer cells. Multiple signaling cascades have been suggested to modulate TRAIL-induced signaling. ER stress has also been noted to intricately stimulate DR5 expression in cancer cells. In accordance with this approach, various natural and synthetic agents have been shown to enhance expression of DR4 and DR5 in cancer cells. In the following section, we discuss the relevant literature highlighting natural agents reportedly involved in stimulating DR5 expression in cancer cells via the ER stress pathway.

PERK-eIF2 $\alpha$ and ATF4-CHOP were notably enhanced in p53-deficient colorectal cancer cells treated with zerumbone (ZER) and celecoxib [60]. ROS scavengers drastically reduced CHOP expression. Interestingly, CHOP motif and ATF/cAMP response element motifs were identified at the proximal region of DR5 gene promoter. ATF3 depletion reduced DR5 expression and enforced expression of ATF3 significantly increased DR5 expression [60]. Histone deacetylase inhibitors (HDACi) also effectively induced activation of PERK and eIF2 $\alpha$ in p53-deficient colorectal cancer cells [61]. Moreover, ATF4/ATF3/CHOP-mediated upregulation of DR5 was also notable in p53-deficient cancer cells. Agonistic anti-DR5 monoclonal antibody markedly enhanced apoptosis in cells treated with HDACi [61]. PKC $\delta$ is a member of the protein kinase $\mathrm{C}$ (PKC) family and undergoes proteolytic cleavage between catalytic domain and regulatory domain in stressed cells. CHOP and DR5 were not enhanced in ATF3- and ATF4-depleted cancer cells treated with bortezomib, a proteasome inhibitor [62]. It is also relevant to mention that MAPK-extracellular signal-regulated kinase (ERK) inhibitor, U0126, also impaired bortezomib-mediated increase in DR5. ATF4, ATF3, and $\mathrm{CHOP}$ were downregulated in $\mathrm{PKC} \delta$-deficient cancer cells [62].

Casticin, isolated from Fructus viticis and Fructus monensin, a polyether ionophore antibiotic enhanced DR5 via CHOP in different cancer cell lines [63, 64]. A recent report found ER stress responses in TRAIL-treated cancer cells including caspase- 12 activation, while caspase- 12 inhibition prevented apoptosis [65]. $\mathrm{Na}(+)-\mathrm{H}(+)$ exchanger 1 (NHE1) from negatively regulating CHOP in cancer cells. NHE1 inhibitor cariporide-treated cells increased in the CHOP-mediated upregulation of DR5 [66]. Parthenolide, a sesquiterpene lactone, notably increased ATF4 and CHOP in lung cancer cells. Moreover, depletion of either ATF4 or CHOP severely abrogated the parthenolide-mediated upregulation of DR5 [67]. More importantly, JNK and p38 MAPK were also noted to be essential for stimulating expression of DR5 in cancer cells by tocotrienols [68]. Other drugs with similar effects for DR5-mediated ER stress pathways are summarized in Table 1. 
Table 1 Natural products that mediate oxidative stress to enhance DR5 via the ER stress pathway in different cancer cell lines

\begin{tabular}{|c|c|c|c|}
\hline Agents (sources) & Targets & Cancer type/cell lines & References \\
\hline Verrucarin A (from several molds) & $\begin{array}{l}\mathrm{ROS} \uparrow \\
\mathrm{p}-\mathrm{eIF} 2 \alpha \uparrow ; \mathrm{CHOP} \uparrow \\
\mathrm{DR} 5 \uparrow\end{array}$ & Liver cancer cells (TRAIL-resistant Hep3B cells) & [69] \\
\hline Guggulsterone (from Commiphora mukul) & $\begin{array}{l}\mathrm{ROS} \uparrow \\
\mathrm{p}-\mathrm{eIF} 2 \alpha \uparrow ; \mathrm{CHOP} \uparrow \\
\mathrm{DR} 5 \uparrow\end{array}$ & Liver cancer cells (Hep3B; HepG2) & {$[70]$} \\
\hline Curcumin (from turmeric) & $\begin{array}{l}\mathrm{ROS} \uparrow \\
\mathrm{CHOP} \uparrow ; \mathrm{SERCA} 2 \downarrow \\
\mathrm{DR} 5 \uparrow\end{array}$ & Liposarcoma cells (SW872) & {$[71,72]$} \\
\hline 5,7-Dimethoxyflavone (from Leptospermum scoparium) & $\begin{array}{l}\mathrm{ROS} \uparrow \\
\mathrm{CHOP} \uparrow ; \mathrm{GPR} 78 \uparrow ; \mathrm{ATF} 4 \uparrow \\
\mathrm{DR} 5 \uparrow\end{array}$ & Liver cancer cells (Hep3B, Huh-7, Hep G2) & [73] \\
\hline
\end{tabular}

SERCA2 sarcoplasmic/endoplasmic reticulum calcium ATPase 2

\section{Natural products with ROS and ER stress-modulating effects}

Although many natural products have been reported to be ROS inducible [74-76], the role of ER stress was not emphasized. Recently, IRE1-mediated activation of JNK was found to be related to ER stress-induced apoptosis as evidenced by its pro-survival role during ER stress and the ability to reduce oxidative stress. JNK3 level was considerably higher in BH3 mimetic S1-treated ovarian cancer SKOV3/DDP cells. Targeted inhibition of JNK3 improved BH3 mimetic S1induced apoptosis in cancer cells [77]. Peroxiredoxin 4 (PRDX4), an ROS-reducing enzyme, facilitates the appropriate folding of proteins in ER and frequently upregulates proteins in high-grade glioma cells [78]. Piperlongumine, a natural plant product effectively inhibited PRDX4 in glioma cells [79]. B cell-specific transcription factor (BACH2), a transcriptional repressor, has been reported to inhibit expression of antioxidant enzymes (superoxide dismutase and catalase) and antiapoptotic genes (BCL2, Bcl-xL, and MCL-1). Bortezomib has been shown to downregulate antioxidant and antiapoptotic genes by promoting nuclear accumulation of BACH2 in mantle cell lymphoma Jeko and SP53 cells [80].

PERK and IRE1 have been noted to be active in colon cancer SW480 cells treated with extracts of brown alga Dictyopteris undulata (DUE) [81]. Moreover, proteolytically processed ATF6 and CHOP were notably enhanced in DUEtreated cancer cells. Knockdown by siRNA CHOP can reduce DUE-induced apoptosis [81]. However, there is direct evidence suggesting differential mechanisms of action through which algal products exert influence. Fucoidan isolated from the marine brown alga Fucus vesiculosus has been shown to differentially modulate ER stress sensors [82]. For example, GRP78 was decreased in the fucoidan-treated MDA-MB-231 breast cancer cells. However, in HCT116 colon cancer cells, fucoidan treatment initially enhanced GRP78 expression, followed by a reduction of GRP78 with increasing fucoidan dosages. Moreover, phospho-IRE1 level was reduced and the generation of spliced $\mathrm{X}$-box binding protein 1 splicing (XBP-1s) from unspliced XBP-1 mRNA is also reduced upon treatment. Interestingly, eIF $2 \alpha$ phosphorylation and active eIF $2 \alpha$-mediated upregulation of CHOP were also noticed in breast cancer cells [82].

Sulforaphane, an isothiocyanate isolated from cruciferous vegetables, reportedly enhanced ER stress in terms of GRP78 and CHOP expression in bladder cancer T24 cells coupled with Nrf2-mediated oxidative stress and apoptosis [26]. Using hepatocellular carcinoma Hep3B cells, sulforaphane has also been reported to inhibit cell proliferation and telomerase activity involving oxidative stress [83]. Pretreatment of NAC can restore the inhibitory effects of hTERT expression and Akt phosphorylation by sulforaphane. These results suggest that sulforaphane-induced ROS generation may interplay with its ER stress effects. Other drugs with similar effects for ROS modulating effects to induce and inhibit ER stress pathways are summarized in Table 2.

\section{Conclusion}

Accumulating evidence demonstrates how oxidative stress is generated from natural agents and synthetic chemicals that trigger ER stress-induced apoptosis. This is of particular interest for molecular oncologists. The functionalizing apoptotic machinery through different signaling pathways could be an effective approach in cancer treatment. ER stress-induced transcriptional upregulation of TRAIL receptors can be used to efficiently restore TRAIL-induced apoptosis in TRAILresistant cancers. Several drugs with ROS inductions and repressions have been suggested as being ER stress inducible 
Table 2 Natural products modulating ROS and ER stress activity in cancer and other cell lines

\begin{tabular}{|c|c|c|c|c|}
\hline & Agents & Targets & Cancer and other cell lines & References \\
\hline \multirow[t]{12}{*}{ ER stress inducers } & $\begin{array}{l}\omega \text {-Hydroxyundec-9-enoic } \\
\text { acid ( } \omega \text {-HUA) (from wild } \\
\text { rice (Oryza officinalis)) }\end{array}$ & $\begin{array}{l}\mathrm{ROS} \uparrow \\
\mathrm{CHOP} \uparrow\end{array}$ & $\begin{array}{l}\text { Lung cancer cells (H1299, } \\
\text { A549, HCC } 827)\end{array}$ & [84] \\
\hline & Cantharidin (from the insect & ROS & Lung cancer cells (H460) & {$[85]$} \\
\hline & Mylabris phalerata Pallas) & $\begin{array}{l}\text { GRP78 } ; \text { IRE1 } \alpha \uparrow ; \\
\quad \text { IRE1 } \beta \uparrow ; \text { ATF6 } \alpha \uparrow\end{array}$ & & \\
\hline & $\begin{array}{l}\text { Ampelopsin (from Ampelopsis } \\
\text { grossedentata) }\end{array}$ & $\begin{array}{l}\text { ROS } \\
\text { GRP78 } ; \text { p-PERK } \uparrow ; \text { p-elF } 2 \alpha \uparrow \\
\text { cleaved ATF6 } \alpha \uparrow ; \text { CHOP } \uparrow\end{array}$ & $\begin{array}{l}\text { Breast cancer cells (MCF-7; } \\
\text { MDA-MB-231) }\end{array}$ & {$[86]$} \\
\hline & $\begin{array}{l}\text { Licochalcone A (from licorice } \\
\text { Glycyrrhiza inflate) }\end{array}$ & $\begin{array}{l}\mathrm{ROS} \uparrow \\
\mathrm{CHOP} \uparrow\end{array}$ & Liver cancer cells (HepG2) & [87] \\
\hline & $\begin{array}{l}\text { Isoliquiritigenin (from licorice } \\
\text { Glycyrrhiza glabra) }\end{array}$ & $\begin{array}{l}\mathrm{ROS} \uparrow \\
\mathrm{p}-\mathrm{eIF} 2 \alpha \uparrow ; \mathrm{GRP} 78 \uparrow\end{array}$ & Cervical cancer cells (HeLa) & {$[88]$} \\
\hline & $\begin{array}{l}\text { Brefeldin A (BFA) (from } \\
\quad \text { Penicillium brefeldianum) [89] }\end{array}$ & $\begin{array}{l}\mathrm{ROS} \uparrow \\
\mathrm{XBP} 1 \uparrow ; \mathrm{GRP} 78 \uparrow \\
\mathrm{CHOP} \uparrow\end{array}$ & $\begin{array}{l}\text { Ovarian (OVCAR-3); } \\
\text { lung (A549); colorectal } \\
\text { (colo 205); breast (MDA-MB-231) } \\
\text { cancer cells }\end{array}$ & [90-93] \\
\hline & $\begin{array}{l}\text { Honokiol (HNK) (from Magnolia } \\
\text { obovata) [94] }\end{array}$ & $\begin{array}{l}\mathrm{ROS} \uparrow \\
\mathrm{p}-\mathrm{eIF} 2 \alpha \uparrow ; \mathrm{GRP} 78 \uparrow \\
\mathrm{CHOP} \uparrow\end{array}$ & $\begin{array}{l}\text { Chondrosarcoma (JJ012 and } \\
\text { SW1353); gastric (AGS and } \\
\text { MKN-45) cancer cells }\end{array}$ & [95-98] \\
\hline & $\begin{array}{l}\text { Delta(9)-tetrahydrocannabinol } \\
\text { (THC) (from Cannabis sativa) }\end{array}$ & $\begin{array}{l}\operatorname{ROS} \uparrow \\
\mathrm{p}-\mathrm{eIF} 2 \alpha \uparrow\end{array}$ & Glioblastoma cells (SF126, U251, U87) & {$[99,100]$} \\
\hline & Resveratrol (from grapes) [101] & $\begin{array}{l}\mathrm{ROS} \uparrow \\
\mathrm{XBP} 1 \uparrow ; \mathrm{p}-\mathrm{eIF} 2 \alpha \uparrow ; \mathrm{GRP} 78 \uparrow \\
\mathrm{CHOP} \uparrow\end{array}$ & $\begin{array}{l}\text { Colon (HT29); leukemia } \\
\text { (K562); nasopharyngeal } \\
\text { (NPC-TW076 and NPC-TW039); } \\
\text { gastric (SGC7901); } \\
\text { lung (A549) cancer cells }\end{array}$ & [102-106] \\
\hline & PABA/NO (from plant) [107] & $\begin{array}{l}\mathrm{ROS} \uparrow \\
\mathrm{CHOP} \uparrow\end{array}$ & $\begin{array}{l}\text { Liver (HepG2); leukemia (HL60); } \\
\text { ovarian (SKOV3) cancer cells }\end{array}$ & {$[108,109]$} \\
\hline & $\begin{array}{l}\text { Prodigiosin (from Serratia } \\
\text { marcescens) }\end{array}$ & $\begin{array}{l}\mathrm{ROS} \uparrow \\
\text { p-eIF2 } \alpha \uparrow ; \mathrm{PERK} \uparrow ; \\
\quad \mathrm{GRP} 78 \uparrow ; \mathrm{ATF} 6 \alpha \uparrow \\
\mathrm{CHOP} \uparrow\end{array}$ & $\begin{array}{l}\text { Pancreatic (8898); breast cancer } \\
\text { cells (MCF-7 and MDA-MB-231) }\end{array}$ & {$[110,111]$} \\
\hline \multirow[t]{5}{*}{ ER stress inhibitors } & $\begin{array}{l}\text { Benzodiazepines (from } \\
\text { Aspergillus ochraceus) }\end{array}$ & $\begin{array}{l}\text { ROS } \downarrow \\
\text { GRP78 } \downarrow\end{array}$ & $\begin{array}{l}\text { Mesencephalic Progenitors } \\
\text { (CSM14.1); neurons and } \\
\text { neural stem cells; } \\
\text { pheochromocytoma (PC12) cells }\end{array}$ & {$[112,113]$} \\
\hline & $\begin{array}{l}\text { Baicalein (from Scutellaria } \\
\text { baicalensis Georgi) [114] }\end{array}$ & $\begin{array}{l}\mathrm{ROS} \downarrow \\
\mathrm{CHOP} \downarrow\end{array}$ & $\begin{array}{l}\text { Neuronal HT22 cells; } \\
\text { cardiomyocytes }\end{array}$ & {$[114,115]$} \\
\hline & $\begin{array}{l}\text { Cordycepin (3'-deoxyadenosin) } \\
\quad \text { (from Cordyceps militaris) [116] }\end{array}$ & $\begin{array}{l}\mathrm{ROS} \downarrow \\
\mathrm{CHOP} \downarrow\end{array}$ & Neuronal HT22 cells & [117] \\
\hline & $\begin{array}{l}\text { Kifunensine mannosidase } \\
\text { inhibitor (from Kitasporia } \\
\text { kifunensis) }\end{array}$ & $\begin{array}{l}\text { ER alpha-mannosidase } \downarrow \\
\text { CHOP } \downarrow\end{array}$ & $\begin{array}{l}\text { Endometrial stromal cells } \\
\text { (HIESC); cervical } \\
\text { cancer cells (HeLa) }\end{array}$ & {$[118,119]$} \\
\hline & $\begin{array}{l}\text { 1-Deoxymannojirimycin } \\
\text { hydrochloride (from } \\
\text { Lonchocarpus sericeus) }^{\mathrm{a}}\end{array}$ & $\begin{array}{l}\text { ER alpha-mannosidase } \downarrow \\
\text { CHOP } \downarrow\end{array}$ & Pheochromocytoma (PC12) cells & [120] \\
\hline
\end{tabular}

$P A B A / N O O(2)-[2,4-$ dinitro-5-( $N$-methyl- $N$-4-carboxyphenylamino)phenyl]1-( $N, N$-methylamino) diazen-1-ium-1,2-diolate; prodigiosin 2-methyl3-pentyl-6-methoxyprodiginine

${ }^{a}$ This drug has a different reported effect that inhibition of alpha-mannosidase in liver cancer cells (7721) induces ER stress in terms of CHOP, XBP1, and GRP78 overexpressions [121]

and inhibitory. With ROS modulation, the ER stress effects of drugs were differentially modulated, making them more suitable for therapeutic purposes. The molecular approach needs additional investigation, and data obtained from preclinical studies will help us to identify natural products or synthetic chemicals with suitable therapeutic efficiency but minimal side effects. Pharmacokinetic studies will further shortlist candidates in the ever increasing list of chemopreventive agents. 
Acknowledgments This work was partly supported by funds of the Ministry of Science and Technology (MOST104-2320-B-037-013-MY3), the Kaohsiung Medical University "Aim for the Top Universities Grant, grant No. KMU-TP103A33," the National Sun Yat-sen University-KMU Joint Research Project (\#NSYSU-KMU 104-p036), the Kaohsiung Municipal Ta-Tung Hospital (kmtth-103-026), ChiMei-KMU Joint Project (104CM-KMU-02), and the Health and Welfare surcharge of tobacco products, the Ministry of Health and Welfare, Taiwan, Republic of China (MOHW104-TDU-B-212-124-003). We also thank for the help of English editing by Dr. Hans-Uwe Dahms.

\section{Conflicts of interest None}

Open Access This article is distributed under the terms of the Creative Commons Attribution 4.0 International License (http:// creativecommons.org/licenses/by/4.0/), which permits unrestricted use, distribution, and reproduction in any medium, provided you give appropriate credit to the original author(s) and the source, provide a link to the Creative Commons license, and indicate if changes were made.

\section{References}

1. Wang M, Kaufman RJ. The impact of the endoplasmic reticulum protein-folding environment on cancer development. Nat Rev Cancer. 2014;14:581-97.

2. Hetz C. The unfolded protein response: controlling cell fate decisions under er stress and beyond. Nat Rev Mol Cell Biol. 2012;13: 89-102.

3. Woehlbier U, Hetz C. Modulating stress responses by the UPRosome: a matter of life and death. Trends Biochem Sci. 2011;36:329-37.

4. Schroder M. Endoplasmic reticulum stress responses. Cell Mol Life Sci. 2008;65:862-94.

5. Rainbolt TK, Saunders JM, Wiseman RL. Stress-responsive regulation of mitochondria through the er unfolded protein response. Trends Endocrinol Metab. 2014;25:528-37.

6. Claudio N, Dalet A, Gatti E, Pierre P. Mapping the crossroads of immune activation and cellular stress response pathways. EMBO J. 2013;32:1214-24.

7. Clarke R, Cook KL, Hu R, Facey CO, Tavassoly I, Schwartz JL, et al. Endoplasmic reticulum stress, the unfolded protein response, autophagy, and the integrated regulation of breast cancer cell fate. Cancer Res. 2012;72:1321-31.

8. Shen J, Chen X, Hendershot L, Prywes R. Er stress regulation of atf6 localization by dissociation of bip/grp78 binding and unmasking of Golgi localization signals. Dev Cell. 2002;3:99 111.

9. Schindler AJ, Schekman R. In vitro reconstitution of er-stress induced atf6 transport in copii vesicles. Proc Natl Acad Sci U S A. 2009;106:17775-80.

10. Ye J, Rawson RB, Komuro R, Chen X, Dave UP, Prywes R, et al. Er stress induces cleavage of membrane-bound atf6 by the same proteases that process srebps. Mol Cell. 2000;6:1355-64.

11. Gregersen N, Bross P. Protein misfolding and cellular stress: an overview. Methods Mol Biol. 2010;648:3-23.

12. Clarke R, Shajahan AN, Wang Y, Tyson JJ, Riggins RB, Weiner $\mathrm{LM}$, et al. Endoplasmic reticulum stress, the unfolded protein response, and gene network modeling in antiestrogen resistant breast cancer. Horm Mol Biol Clin Investig. 2011;5:35-44.

13. Hetz C, Martinon F, Rodriguez D, Glimcher LH. The unfolded protein response: Integrating stress signals through the stress sensor ire1alpha. Physiol Rev. 2011;91:1219-43.
14. Schroder M, Kaufman RJ. Divergent roles of ire 1alpha and perk in the unfolded protein response. Curr Mol Med. 2006;6:5-36.

15. Hetz C, Glimcher LH. Fine-tuning of the unfolded protein response: assembling the ire1alpha interactome. Mol Cell. 2009;35:551-61.

16. Han J, Back SH, Hur J, Lin YH, Gildersleeve R, Shan J, et al. Erstress-induced transcriptional regulation increases protein synthesis leading to cell death. Nat Cell Biol. 2013;15:481-90.

17. Novoa I, Zeng H, Harding HP, Ron D. Feedback inhibition of the unfolded protein response by gadd34-mediated dephosphorylation of eif2alpha. J Cell Biol. 2001;153:1011-22.

18. Chaudhari N, Talwar P, Parimisetty A, Lefebvre d'Hellencourt C, Ravanan P. A molecular web: endoplasmic reticulum stress, inflammation, and oxidative stress. Front Cell Neurosci. 2014;8: 213.

19. Ivanova D, Bakalova R, Lazarova D, Gadjeva V, Zhelev Z. The impact of reactive oxygen species on anticancer therapeutic strategies. Adv Clin Exp Med. 2013;22:899-908.

20. Maraldi T. Natural compounds as modulators of nadph oxidases. Oxid Med Cell Longev. 2013;2013:271602.

21. Turrens JF. Mitochondrial formation of reactive oxygen species. J Physiol. 2003;552:335-44.

22. Goldberger RF, Epstein CJ, Anfinsen CB. Acceleration of reactivation of reduced bovine pancreatic ribonuclease by a microsomal system from rat liver. J Biol Chem. 1963;238:628-35.

23. Chakravarthi S, Jessop CE, Bulleid NJ. The role of glutathione in disulphide bond formation and endoplasmic-reticulum-generated oxidative stress. EMBO Rep. 2006;7:271-5.

24. Cullinan SB, Zhang D, Hannink M, Arvisais E, Kaufman RJ, Diehl JA. Nrf2 is a direct perk substrate and effector of perkdependent cell survival. Mol Cell Biol. 2003;23:7198-209.

25. Nguyen T, Sherratt PJ, Pickett CB. Regulatory mechanisms controlling gene expression mediated by the antioxidant response element. Annu Rev Pharmacol Toxicol. 2003;43:233-60.

26. Jo GH, Kim GY, Kim WJ, Park KY, Choi YH. Sulforaphane induces apoptosis in t24 human urinary bladder cancer cells through a reactive oxygen species-mediated mitochondrial pathway: the involvement of endoplasmic reticulum stress and the nrf2 signaling pathway. Int J Oncol. 2014;45:1497-506.

27. Bobrovnikova-Marjon E, Grigoriadou C, Pytel D, Zhang F, Ye J, Koumenis C, et al. Perk promotes cancer cell proliferation and tumor growth by limiting oxidative DNA damage. Oncogene. 2010;29:3881-95.

28. Malhotra JD, Kaufman RJ. Er stress and its functional link to mitochondria: role in cell survival and death. Cold Spring Harb Perspect Biol. 2011;3:a004424.

29. Grimm S. The er-mitochondria interface: the social network of cell death. Biochim Biophys Acta. 1823;2012:327-34.

30. Verfaillie T, Rubio N, Garg AD, Bultynck G, Rizzuto R, Decuypere JP, et al. Perk is required at the er-mitochondrial contact sites to convey apoptosis after ros-based er stress. Cell Death Differ. 2012;19:1880-91.

31. Tabas I, Ron D. Integrating the mechanisms of apoptosis induced by endoplasmic reticulum stress. Nat Cell Biol. 2011;13:184-90.

32. Kim I, Xu W, Reed JC. Cell death and endoplasmic reticulum stress: disease relevance and therapeutic opportunities. Nat Rev Drug Discov. 2008;7:1013-30.

33. Su TR, Tsai FJ, Lin JJ, Huang HH, Chiu CC, Su JH, et al. Induction of apoptosis by 11-dehydrosinulariolide via mitochondrial dysregulation and er stress pathways in human melanoma cells. Mar Drugs. 2012;10:1883-98.

34. Chang YJ, Huang CY, Hung CS, Liu HH, Wei PL. Glucoseregulated protein 78 mediates the therapeutic efficacy of 17 dmag in colon cancer cells. Tumour Biol 2015 
35. Xia Z, Dickens M, Raingeaud J, Davis RJ, Greenberg ME. Opposing effects of erk and jnk-p38 map kinases on apoptosis. Science. 1995;270:1326-31.

36. Zerbini LF, de Vasconcellos JF, Czibere A, Wang Y, Paccez JD, $\mathrm{Gu} \mathrm{X}$, et al. Jund-mediated repression of gadd45alpha and gamma regulates escape from cell death in prostate cancer. Cell Cycle. 2011;10:2583-91.

37. Teske BF, Fusakio ME, Zhou D, Shan J, McClintick JN, Kilberg MS, et al. Chop induces activating transcription factor 5 (atf5) to trigger apoptosis in response to perturbations in protein homeostasis. Mol Biol Cell. 2013;24:2477-90.

38. Chiribau CB, Gaccioli F, Huang CC, Yuan CL, Hatzoglou M. Molecular symbiosis of chop and c/ebp beta isoform lip contributes to endoplasmic reticulum stress-induced apoptosis. Mol Cell Biol. 2010;30:3722-31.

39. Primor N, Tu AT. Conformation of pardaxin, the toxin of the flatfish Pardachirus marmoratus. Biochim Biophys Acta. 1980;626:299-306.

40. Hsu JC, Lin LC, Tzen JT, Chen JY. Pardaxin-induced apoptosis enhances antitumor activity in hela cells. Peptides. 2011;32:1110-6.

41. Huang TC, Lee JF, Chen JY. Pardaxin, an antimicrobial peptide, triggers caspase-dependent and ros-mediated apoptosis in ht-1080 cells. Mar Drugs. 2011;9:1995-2009.

42. Wu SP, Huang TC, Lin CC, Hui CF, Lin CH, Chen JY. Pardaxin, a fish antimicrobial peptide, exhibits antitumor activity toward murine fibrosarcoma in vitro and in vivo. Mar Drugs. 2012;10:1852-72.

43. Huang TC, Chen JY. Proteomic analysis reveals that pardaxin triggers apoptotic signaling pathways in human cervical carcinoma hela cells: cross talk among the upr, c-jun and ros. Carcinogenesis. 2013;34:1833-42.

44. Xie J, Xu Y, Huang X, Chen Y, Fu J, Xi M, et al. Berberineinduced apoptosis in human breast cancer cells is mediated by reactive oxygen species generation and mitochondrial-related apoptotic pathway. Tumour Biol. 2015;36:1279-88.

45. Rico-Bautista E, Zhu W, Kitada S, Ganapathy S, Lau E, Krajewski $\mathrm{S}$, et al. Small molecule-induced mitochondrial disruption directs prostate cancer inhibition via upr signaling. Oncotarget. 2013;4: 1212-29.

46. Shen S, Zhang Y, Zhang R, Gong X. Sarsasapogenin induces apoptosis via the reactive oxygen species-mediated mitochondrial pathway and er stress pathway in hela cells. Biochem Biophys Res Commun. 2013;441:519-24.

47. Shin SY, Lee JM, Lee MS, Koh D, Jung H, Lim Y, et al. Targeting cancer cells via the reactive oxygen species-mediated unfolded protein response with a novel synthetic polyphenol conjugate. Clin Cancer Res. 2014;20:4302-13.

48. Min KJ, Jung KJ, Kwon TK. Carnosic acid induces apoptosis through reactive oxygen species-mediated endoplasmic reticulum stress induction in human renal carcinoma caki cells. J Cancer Prev. 2014;19:170-8.

49. Goda AE, Erikson RL, Sakai T, Ahn JS, Kim BY. Preclinical evaluation of bortezomib/dipyridamole novel combination as a potential therapeutic modality for hematologic malignancies. Mol Oncol 2014:in press [PMID: 25245324].

50. Palombo F, Focaccetti C, Barnaba V. Therapeutic implications of immunogenic cell death in human cancer. Front Immunol. 2014;4:503

51. Krysko DV, Garg AD, Kaczmarek A, Krysko O, Agostinis P, Vandenabeele P. Immunogenic cell death and damps in cancer therapy. Nat Rev Cancer. 2012;12:860-75.

52. Panaretakis T, Kepp O, Brockmeier U, Tesniere A, Bjorklund AC, Chapman DC, et al. Mechanisms of pre-apoptotic calreticulin exposure in immunogenic cell death. EMBO J. 2009;28:578-90.
53. Yang Y, Li XJ, Chen Z, Zhu XX, Wang J, Zhang LB, et al. Wogonin induced calreticulin/annexin a1 exposure dictates the immunogenicity of cancer cells in a perk/akt dependent manner. PLoS One. 2012; 7:e50811.

54. Krysko O, Love Aaes T, Bachert C, Vandenabeele P, Krysko DV. Many faces of damps in cancer therapy. Cell Death Dis. 2013;4:e631.

55. Garg AD, Dudek AM, Agostinis P. Cancer immunogenicity, danger signals, and damps: what, when, and how? Biofactors. 2013;39:355-67.

56. Vacchelli E, Aranda F, Eggermont A, Galon J, Sautes-Fridman C, Cremer I, et al. Trial watch: chemotherapy with immunogenic cell death inducers. Oncoimmunology. 2014;3:e27878.

57. Hou W, Zhang Q, Yan Z, Chen R, Zeh Iii HJ, Kang R, et al. Strange attractors: damps and autophagy link tumor cell death and immunity. Cell Death Dis. 2013;4:e966.

58. Zheng Y, Yin G, Le V, Zhang A, Lu Y, Yang M, et al. Hypericinbased photodynamic therapy induces a tumor-specific immune response and an effective dc-based cancer immunotherapy. Biochem Pharmacol 2014:in press [PMID: 24508834].

59. Farooqi AA, Yaylim I, Ozkan NE, Zaman F, Halim TA, Chang HW. Restoring trail mediated signaling in ovarian cancer cells. Arch Immunol Ther Exp (Warsz) 2014:in press.

60. Edagawa M, Kawauchi J, Hirata M, Goshima H, Inoue M, Okamoto $\mathrm{T}$, et al. Role of activating transcription factor 3 (atf3) in endoplasmic reticulum (er) stress-induced sensitization of p53deficient human colon cancer cells to tumor necrosis factor (tnf)related apoptosis-inducing ligand (trail)-mediated apoptosis through up-regulation of death receptor $5(\mathrm{dr} 5)$ by zerumbone and celecoxib. J Biol Chem. 2014;289:21544-61.

61. Liu J, Edagawa M, Goshima H, Inoue M, Yagita H, Liu Z, et al. Role of atf3 in synergistic cancer cell killing by a combination of hdac inhibitors and agonistic anti-dr5 antibody through er stress in human colon cancer cells. Biochem Biophys Res Commun. 2014;445:320-6.

62. Xu L, Su L, Liu X. Pkcdelta regulates death receptor 5 expression induced by ps-341 through atf4-atf3/chop axis in human lung cancer cells. Mol Cancer Ther. 2012;11:2174-82.

63. Zhou Y, Tian L, Long L, Quan M, Liu F, Cao J. Casticin potentiates trail-induced apoptosis of gastric cancer cells through endoplasmic reticulum stress. PLoS One. 2013;8:e58855.

64. Yoon MJ, Kang YJ, Kim IY, Kim EH, Lee JA, Lim JH, et al. Monensin, a polyether ionophore antibiotic, overcomes trail resistance in glioma cells via endoplasmic reticulum stress, dr5 upregulation and c-flip downregulation. Carcinogenesis. 2013;34: 1918-28.

65. Inoue T, Suzuki-Karasaki Y. Mitochondrial superoxide mediates mitochondrial and endoplasmic reticulum dysfunctions in trailinduced apoptosis in jurkat cells. Free Radic Biol Med. 2013;61: 273-84.

66. Li H, Chang G, Wang J, Wang L, Jin W, Lin Y, et al. Cariporide sensitizes leukemic cells to tumor necrosis factor related apoptosis-inducing ligand by up-regulation of death receptor 5 via endoplasmic reticulum stress-ccaat/enhancer binding protein homologous protein dependent mechanism. Leuk Lymphoma. 2014;55:2135-40.

67. Zhao X, Liu X, Su L. Parthenolide induces apoptosis via tnfrsf10b and pmaip1 pathways in human lung cancer cells. J Exp Clin Cancer Res. 2014;33:3.

68. Park SK, Sanders BG, Kline K. Tocotrienols induce apoptosis in breast cancer cell lines via an endoplasmic reticulum stressdependent increase in extrinsic death receptor signaling. Breast Cancer Res Treat. 2010;124:361-75.

69. Moon DO, Asami Y, Long H, Jang JH, Bae EY, Kim BY, et al Verrucarin a sensitizes trail-induced apoptosis via the upregulation 
of dr5 in an eif2alpha/chop-dependent manner. Toxicol In Vitro. 2013;27:257-63.

70. Moon DO, Park SY, Choi YH, Ahn JS, Kim GY. Guggulsterone sensitizes hepatoma cells to trail-induced apoptosis through the induction of chop-dependent dr5: involvement of ros-dependent er-stress. Biochem Pharmacol. 2011;82:1641-50.

71. Wang L, Wang L, Song R, Shen Y, Sun Y, Gu Y, et al. Targeting sarcoplasmic/endoplasmic reticulum ca(2)+-atpase 2 by curcumin induces er stress-associated apoptosis for treating human liposarcoma. Mol Cancer Ther. 2011;10:461-71.

72. Lin SS, Huang HP, Yang JS, Wu JY, Hsia TC, Lin CC, et al. DNA damage and endoplasmic reticulum stress mediated curcumininduced cell cycle arrest and apoptosis in human lung carcinoma a-549 cells through the activation caspases cascade- and mitochondrial-dependent pathway. Cancer Lett. 2008;272:77-90.

73. Yang JF, Cao JG, Tian L, Liu F. 5, 7-dimethoxyflavone sensitizes trail-induced apoptosis through dr5 upregulation in hepatocellular carcinoma cells. Cancer Chemother Pharmacol. 2012;69:195-206.

74. Farooqi AA, Fayyaz S, Hou MF, Li KT, Tang JY, Chang HW. Reactive oxygen species and autophagy modulation in nonmarine drugs and marine drugs. Mar Drugs. 2014;12:5408-24.

75. Yen YH, Farooqi AA, Li KT, Butt G, Tang JY, Wu CY, et al. Methanolic extracts of Solieria robusta inhibits proliferation of oral cancer ca9-22 cells via apoptosis and oxidative stress. Molecules. 2014;19:18721-32.

76. Lee JC, Hou MF, Huang HW, Chang FR, Yeh CC, Tang JY, et al. Marine algal natural products with anti-oxidative, anti-inflammatory, and anti-cancer properties. Cancer Cell Int. 2013;13:55.

77. Yang X, Xiang X, Xia M, Su J, Wu Y, Shen L, et al. Inhibition of jnk3 promotes apoptosis induced by bh3 mimetic s1 in chemoresistant human ovarian cancer cells. Anat Rec (Hoboken) 2014:in press [PMID: 25044439].

78. Kim TH, Song J, Alcantara Llaguno SR, Murnan E, Liyanarachchi S, Palanichamy K, et al. Suppression of peroxiredoxin 4 in glioblastoma cells increases apoptosis and reduces tumor growth. PLoS One. 2012;7:e42818.

79. Kim TH, Song J, Kim SH, Parikh AK, Mo X, Palanichamy K, et al. Piperlongumine treatment inactivates peroxiredoxin 4 , exacerbates endoplasmic reticulum stress, and preferentially kills highgrade glioma cells. Neuro Oncol. 2014;16:1354-64.

80. Chen Z, Pittman EF, Romaguera J, Fayad L, Wang M, Neelapu $\mathrm{SS}$, et al. Nuclear translocation of b-cell-specific transcription factor, bach2, modulates ros mediated cytotoxic responses in mantle cell lymphoma. PLoS One. 2013;8:e69126.

81. Kang KA, Kim JK, Jeong YJ, Na SY, Hyun JW. Dictyopteris undulata extract induces apoptosis via induction of endoplasmic reticulum stress in human colon cancer cells. J Cancer Prev. 2014;19:118-24.

82. Chen S, Zhao Y, Zhang Y, Zhang D. Fucoidan induces cancer cell apoptosis by modulating the endoplasmic reticulum stress cascades. PLoS One. 2014;9:e108157.

83. Moon DO, Kang SH, Kim KC, Kim MO, Choi YH, Kim GY. Sulforaphane decreases viability and telomerase activity in hepatocellular carcinoma hep3b cells through the reactive oxygen species-dependent pathway. Cancer Lett. 2010;295:260-6.

84. Yang KM, Kim BM, Park JB. Omega-hydroxyundec-9-enoic acid induces apoptosis through ros-mediated endoplasmic reticulum stress in non-small cell lung cancer cells. Biochem Biophys Res Commun. 2014;448:267-73.

85. Hsia TC, Yu CC, Hsu SC, Tang NY, Lu HF, Huang YP, et al. Cantharidin induces apoptosis of h460 human lung cancer cells through mitochondria-dependent pathways. Int J Oncol. 2014;45: $245-54$.

86. Zhou Y, Shu F, Liang X, Chang H, Shi L, Peng X, et al. Ampelopsin induces cell growth inhibition and apoptosis in breast cancer cells through ros generation and endoplasmic reticulum stress pathway. PLoS One. 2014;9:e89021.

87. Choi AY, Choi JH, Hwang KY, Jeong YJ, Choe W, Yoon KS, et al. Licochalcone a induces apoptosis through endoplasmic reticulum stress via a phospholipase cgamma1-, ca(2+)-, and reactive oxygen species-dependent pathway in hepg2 human hepatocellular carcinoma cells. Apoptosis. 2014;19:682-97.

88. Yuan X, Zhang B, Gan L, Wang ZH, Yu BC, Liu LL, et al. Involvement of the mitochondrion-dependent and the endoplasmic reticulum stress-signaling pathways in isoliquiritigenininduced apoptosis of hela cell. Biomed Environ Sci. 2013;26: 268-76.

89. Shao RG, Shimizu T, Pommier Y. Brefeldin a is a potent inducer of apoptosis in human cancer cells independently of p53. Exp Cell Res. 1996;227:190-6.

90. Lee SA, Kim YJ, Lee CS. Brefeldin a induces apoptosis by activating the mitochondrial and death receptor pathways and inhibits focal adhesion kinase-mediated cell invasion. Basic Clin Pharmacol Toxicol. 2013;113:329-38.

91. Moon JL, Kim SY, Shin SW, Park JW. Regulation of brefeldin ainduced er stress and apoptosis by mitochondrial nadp $(+)$-dependent isocitrate dehydrogenase. Biochem Biophys Res Commun. 2012;417:760-4.

92. Tseng CN, Huang CF, Cho CL, Chang HW, Huang CW, Chiu CC, et al. Brefeldin a effectively inhibits cancer stem cell-like properties and mmp-9 activity in human colorectal cancer colo 205 cells. Molecules. 2013;18:10242-53.

93. Tseng CN, Hong YR, Chang HW, Yu TJ, Hung TW, Hou MF, et al. Brefeldin a reduces anchorage-independent survival, cancer stem cell potential and migration of mda-mb-231 human breast cancer cells. Molecules. 2014;19:17464-77.

94. Munroe ME, Arbiser JL, Bishop GA. Honokiol, a natural plant product, inhibits inflammatory signals and alleviates inflammatory arthritis. J Immunol. 2007;179:753-63.

95. Hahm ER, Sakao K, Singh SV. Honokiol activates reactive oxygen species-mediated cytoprotective autophagy in human prostate cancer cells. Prostate 2014:in press.

96. Chen YJ, Wu CL, Liu JF, Fong YC, Hsu SF, Li TM, et al. Honokiol induces cell apoptosis in human chondrosarcoma cells through mitochondrial dysfunction and endoplasmic reticulum stress. Cancer Lett. 2010;291:20-30.

97. Pan HC, Lai DW, Lan KH, Shen CC, Wu SM, Chiu CS, et al. Honokiol thwarts gastric tumor growth and peritoneal dissemination by inhibiting tpl2 in an orthotopic model. Carcinogenesis. 2013;34:2568-79.

98. Weng TI, Wu HY, Chen BL, Liu SH. Honokiol attenuates the severity of acute pancreatitis and associated lung injury via acceleration of acinar cell apoptosis. Shock. 2012;37:478-84.

99. Marcu JP, Christian RT, Lau D, Zielinski AJ, Horowitz MP, Lee J, et al. Cannabidiol enhances the inhibitory effects of delta9tetrahydrocannabinol on human glioblastoma cell proliferation and survival. Mol Cancer Ther. 2010;9:180-9.

100. Salazar M, Carracedo A, Salanueva IJ, Hernandez-Tiedra S, Lorente M, Egia A, et al. Cannabinoid action induces autophagy-mediated cell death through stimulation of er stress in human glioma cells. J Clin Invest. 2009;119:1359-72.

101. Jang M, Cai L, Udeani GO, Slowing KV, Thomas CF, Beecher $\mathrm{CW}$, et al. Cancer chemopreventive activity of resveratrol, a natural product derived from grapes. Science. 1997;275:218-20.

102. Park JW, Woo KJ, Lee JT, Lim JH, Lee TJ, Kim SH, et al. Resveratrol induces pro-apoptotic endoplasmic reticulum stress in human colon cancer cells. Oncol Rep. 2007;18:1269-73.

103. Liu BQ, Gao YY, Niu XF, Xie JS, Meng X, Guan Y, et al. Implication of unfolded protein response in resveratrol-induced inhibition of k562 cell proliferation. Biochem Biophys Res Commun. 2010;391:778-82. 
104. Wang Z, Li W, Meng X, Jia B. Resveratrol induces gastric cancer cell apoptosis via reactive oxygen species, but independent of sirtuin1. Clin Exp Pharmacol Physiol. 2012;39:227-32.

105. Luo H, Yang A, Schulte BA, Wargovich MJ, Wang GY. Resveratrol induces premature senescence in lung cancer cells via ros-mediated DNA damage. PLoS One. 2013;8:e60065.

106. Son Y, Lee JH, Chung HT, Pae HO. Therapeutic roles of heme oxygenase-1 in metabolic diseases: curcumin and resveratrol analogues as possible inducers of heme oxygenase-1. Oxid Med Cell Longev. 2013;2013:639541.

107. Liu J. Pharmacology of oleanolic acid and ursolic acid. J Ethnopharmacol. 1995;49:57-68.

108. Liu L, Fu J, Li T, Cui R, Ling J, Yu X, et al. Ng, a novel paba/nobased oleanolic acid derivative, induces human hepatoma cell apoptosis via a ros/mapk-dependent mitochondrial pathway. Eur J Pharmacol. 2012;691:61-8.

109. Townsend DM, Manevich Y, He L, Xiong Y, Bowers Jr RR, Hutchens $S$, et al. Nitrosative stress-induced $\mathrm{s}$ glutathionylation of protein disulfide isomerase leads to activation of the unfolded protein response. Cancer Res. 2009;69: 7626-34.

110. Pan MY, Shen YC, Lu CH, Yang SY, Ho TF, Peng YT, et al. Prodigiosin activates endoplasmic reticulum stress cell death pathway in human breast carcinoma cell lines. Toxicol Appl Pharmacol. 2012;265:325-34.

111. Zhang J, Liu J, Shen Y, Wei D, Li K. Inhibitive effect of prodigiosin on the proliferation of human malignant pancreatic cancer cells. Med Chem Res. 2005;14:181-97.

112. Park SW, Lee CH, Lee JG, Kim LW, Shin BS, Lee BJ, et al. Protective effects of atypical antipsychotic drugs against mpp $(+)$ induced oxidative stress in pc12 cells. Neurosci Res. 2011;69: 283-90.

113. Kurosawa S, Hashimoto E, Ukai W, Toki S, Saito S, Saito T. Olanzapine potentiates neuronal survival and neural stem cell differentiation: regulation of endoplasmic reticulum stress response proteins. J Neural Transm. 2007;114:1121-8.
114. Chen HM, Hsu JH, Liou SF, Chen TJ, Chen LY, Chiu CC, et al. Baicalein, an active component of Scutellaria baicalensis Georgi, prevents lysophosphatidylcholine-induced cardiac injury by reducing reactive oxygen species production, calcium overload and apoptosis via mapk pathways. BMC Complement Altern Med. 2014;14:233.

115. Choi JH, Choi AY, Yoon H, Choe W, Yoon KS, Ha J, et al. Baicalein protects ht 22 murine hippocampal neuronal cells against endoplasmic reticulum stress-induced apoptosis through inhibition of reactive oxygen species production and chop induction. Exp Mol Med. 2010;42:811-22.

116. Jeong JW, Jin CY, Park C, Hong SH, Kim GY, Jeong YK, et al. Induction of apoptosis by cordycepin via reactive oxygen species generation in human leukemia cells. Toxicol In Vitro. 2011;25: 817-24.

117. Jin ML, Park SY, Kim YH, Oh JI, Lee SJ, Park G. The neuroprotective effects of cordycepin inhibit glutamate-induced oxidative and er stress-associated apoptosis in hippocampal ht22 cells. Neurotoxicology. 2014;41:102-11.

118. Singh M, Chaudhry P, Parent S, Asselin E. Ubiquitin-proteasomal degradation of cox-2 in tgf-beta stimulated human endometrial cells is mediated through endoplasmic reticulum mannosidase i. Endocrinology. 2012;153:426-37.

119. Elfrink HL, Zwart R, Baas F, Scheper W. Inhibition of endoplasmic reticulum associated degradation reduces endoplasmic reticulum stress and alters lysosomal morphology and distribution. Mol Cells. 2013;35:291-7.

120. Miyake K, Nagai K. Inhibition of alpha-mannosidase attenuates endoplasmic reticulum stress-induced neuronal cell death. Neurotoxicology. 2009;30:144-50.

121. Lu Y, Xu YY, Fan KY, Shen ZH. 1-deoxymannojirimycin, the alpha1,2-mannosidase inhibitor, induced cellular endoplasmic reticulum stress in human hepatocarcinoma cell 7721. Biochem Biophys Res Commun. 2006;344:221-5. 